\title{
Neighborhoods by Assessment: An Analysis of Non-Ad Valorem Financing In California
}

\begin{abstract}
:
Non-ad valorem assessments on property are a fiscal innovation born from financial stress. Unable to raise property taxes due to limitations, many localities have turned to these charges as an alternative method to fund local services. In this paper, we seek to explain differential levels of non-ad valorem assessment financing through the analysis of property tax records of a large and diverse set of single family homes in California. We theorize that assessments, as opposed to other forms of taxation, will be used when residents hold anti-redistributive preferences. We show that assessment financing is most common in cities with high median household incomes and greater ethnic diversity. We also show that certain types of assessments, those with narrow geographic range, are frequently levied on expensive homes in poorer communities. We argue that this new form of financing exacerbates economic inequality by creating additional inequities in public service provisions.
\end{abstract}

Mathew D. McCubbins

Ruth F. De Varney Professor of Political Science and Professor of Law

Duke University

Ellen C. Seljan

eseljan@1clark.edu

Assistant Professor of Political Science

Lewis \& Clark College

We would like to acknowledge generous funding from the Keston Institute for Infrastructure and the Initiative and Referendum Institute at the University of Southern California for data collection for this project. 


\section{Neighborhoods by Assessment: An Analysis of Non-Ad Valorem Financing In California}

Since the passage of California's Proposition 13 in 1978, American state and local governments have been swept by a populist "tax revolt" designed to limit the reach and breadth of public taxation (Martin 2008; Moule and Weller 2011). Efforts to reduce property taxes have been at the heart of the revolt, and today more than twenty-six states have constitutional and statutory limits on the taxation of real property. Tax limitations however, have not fundamentally transformed the nature of local government - they have neither reduced constituent demand for public services nor the cost of their provision (see Sears and Citrin 1982). Instead, to maintain services, local officials have responded by finding new, creative ways to raise new revenues (Mullins and Joyce 1996; Skidmore 1999; Hoene 2004; Thompson and Green 2004). These public finance innovations have generally been significantly more opaque (Chapman 1998) and less progressive than their forerunners (Waters et al. 1997).

This paper seeks to understand variation within cities and neighborhoods on how public services are funded in the face of property tax limitation. Our focus is on non-ad valorem assessments, particularly popular, but understudied sources of local revenues. Originally designed to pay for local infrastructure projects, in recent decades this type of assessment has been increasingly used to provide a growing number of public services, from local fire and police protection to street maintenance and repair (Kogan and McCubbins 2008). By allowing subsets of geographically defined residents to come together to form assessment districts, this financing mechanism has greatly weakened the link between the overall financial health of local governments and the service levels experienced by individual taxpayers, households, and businesses, giving rise to new centrifugal political forces within U.S. cities. 
In this paper we analyze the correlates of non-ad valorem assessment financing using a large and diverse sample of California single-family homes. We argue that assessments, as opposed to other forms of taxation, will be used when residents hold anti-redistributive preferences. We demonstrate that assessment financing is more common in cities with high median household incomes and greater ethnic diversity. We also show that certain types of assessments, those with the most limited geographic ranges, are most frequently levied on expensive homes in poorer communities. We argue that non-ad valorem assessments exacerbate economic disparities by creating additional inequities in the provision of public services.

This paper proceeds as follows. The next section provides a brief historical overview of assessment financing in the United States, highlighting the evolution of this revenue source in the face of growing fiscal stress. Next, building on the recent literature on local political economy, we develop hypotheses about variation in the incidence of assessment financing and, in the subsequent section, test them using an original dataset of property tax bills in California. The analysis is then expanded to more closely examine the narrowest types of assessment, what we deem "club assessments". The final section discusses the findings and considers the broader implications of non-ad valorem assessment financing for U.S. inequality.

\section{The Rise of Non-Ad Valorem Assessments}

Historically, general taxes and user fees represented the two primary sources of revenue raised locally by municipal governments. Taxes, whether from property, income, sales, or other sources, are universal in that all residents pay them, regardless of whether they use or want the public services funded by their tax dollars. By contrast, user fees are charges collected from individuals who voluntarily take part in specific government programs and are collected roughly 
in proportion to the level of individual use (Mikesell 2010). According to one scholar, non-ad valorem assessments are a "halfway house between the property tax and the user charge" (Land 1967, 89). Like taxes, these assessments are compulsory in that the property owners within a geographically defined region are required to pay the levy, regardless of whether they desire or personally use the public services that the assessment funds. Like user fees, the amount charged to each person or entity is theoretically considered to be related to the level of service that is provided, often calculated as the amount of "benefit" the user is deemed to receive. This type of financing can provide a vehicle to provide local "club" goods — public goods with limited geographic reach that can not feasibly be paid for by user fees due to their non-excludable nature. ${ }^{1}$

While rarely discussed in the literature, non-ad valorem taxes are not rare and not new. The tradition of assessing non-ad valorem charges for certain public benefits dates back more than 700 years, when residents in one seaside England city were assessed for repairs made to nearby seawalls (Rosewater 1968). The assessment was based on the proportion that each resident's property deemed to benefit. In the United States the first known use of this type of financing occurred in 1691 when New York City used assessments to finance the construction of street and water drainage systems (Misczynski 1978). Misczynski estimates that by 1913 the largest U.S. cities obtained an average of 12 percent of their revenue from such assessments, with the four largest raising more than 20 percent of their funds in this way. Although assessments became less popular in the wake of the Great Depression due to a series of defaults

\footnotetext{
${ }^{1}$ Club goods, like public goods, are non-excludable, producing strong incentives to free ride on their provision.

2 California Legislative Analyst's Office. 2012. "Understanding California's Property Taxes". Available at http://www.lao.ca.gov/reports/2012/tax/property-tax-primer-112912.aspx
} 
on bonds backed by assessment dollars, assessment financing, especially of infrastructure, was again on the rise in the second half of the twentieth century (Misczynski 1978).

While non-ad valorem assessments can be found across the country, they are used extensively in California. Specifically, in California, they exist in three forms: special assessments, parcel taxes, and community facility district Mello-Roos taxes. ${ }^{2}$ Special assessments are used to fund public services that provide benefits to real property, not the inhabitants of properties, an important distinction (California Legislative Analyst's Office 2012). For example, legally, special assessments can be used to fund neighborhood lighting, parks, and street maintenance, but not schools. The amount charged to each property is calculated as the amount of benefit received by the property, determined by a "benefit engineer" who may or may not rely on rules of thumb such as local land-use designations, size of the property, length of the property line abutting a street but not value to make their calculations (Misczynski 1978). In contrast, parcel taxes can be used for a greater breadth of services, including schools, libraries, or matters of public safety. Here, the primary limitation is on the calculation of charges; all parcel taxes must be assessed equally across properties ("parcels"), regardless of the property value, size, or benefit received. Finally, Mello-Roos taxes are the most flexible form of non-ad valorem assessment. They can fund any type of public service and be levied based on a variety of formulas

The mechanism for adopting these three forms of non-ad valorem assessments varies. Special assessments can be adopted by a majority of property owners whose votes are weighted by their properties' expected benefits (see Kogan and McCubbins 2008 for an overview and

\footnotetext{
${ }^{2}$ California Legislative Analyst's Office. 2012. "Understanding California's Property Taxes". Available at http://www.lao.ca.gov/reports/2012/tax/property-tax-primer-112912.aspx
} 
critique of the formation process) $)^{3}$. Mello-Roos taxes similarly require approval by weighted property owners, but always require two-thirds approval. Finally, parcel taxes require the approval of two-thirds of all voters, not property owners.

For most of their history, non-ad valorem assessments in California have been used to finance the construction of infrastructure projects with clearly limited geographic reach. For example, assessments have paid for the construction of roads in remote areas, with each property owner contributing in proportion to the length of their property that is adjacent to the roadway. Most frequently assessments have been used to build projects that benefited both specific property owners and the community nearby, such as neighborhood lighting and sidewalks. However, the scope of special assessment financing has greatly expanded over the last three decades.

In large part, this expansion has been fueled by the growing limits to local governments' ability to increase general taxes in order to provide public services (Kogan and McCubbins 2008). In an important 1979 decision California courts ruled that Proposition 13, a constitutional amendment approved by California voters the year before that greatly limited local property taxes, did not cover special assessments. Although assessments usually appear on the property tax bill received by homeowners, an appellate court ruled that a "special assessment is charged to real property to pay for benefits that property has received from a local improvement and, strictly speaking, is not a tax at all" (County of Fresno v. Malmstrom 1979). The potential of non-ad valorem assessments to replace revenue lost due to Proposition 13 quickly became apparent to observers in and outside of government. Testifying at a 1986 hearing, one state lawmaker noted that "benefit assessments have become a growth industry in California" and the California

\footnotetext{
${ }^{3}$ Special assessments for specific, not general, purposes require a $2 / 3$ majority since the passage of Proposition 218 in 1996.
} 
Taxpayers Association described them "a born again revenue raiser" (Senate Committee on Local Government 1986). ${ }^{4}$

\section{Strategy and Choice in Municipal Service Delivery}

Today California taxpayers wishing to increase local public services have two broad choices. One alternative is to increase traditional revenue sources. This can be done through changes to the sales tax or by passing general obligation bonds to increase property taxes, which are otherwise capped by Proposition 13. Both of these forms of taxation employ a flat tax rate with respect to its base. Although by definition this is not a progressive form of taxation - no local government tax generally is - it does mean that those with higher consumption or more expensive homes will nominally pay more than those with smaller consumption habits or abilities.

Another option is to band together with other like-minded, geographically proximate individuals and form a non-ad valorem assessment district. Such districts constrain the redistributive consequences of government spending in two ways. First, a district can limit services to a small, often heavily gerrymandered, geographic area. This effectively precludes redistribution by limiting access to public services to those who live in the area and pay for the service. Second, a district can be funded using a flat, lump-sum fee or another benefit calculation with a similar distributive impact. This limits redistribution by equalizing payments more or less regardless of ability to pay.

\footnotetext{
${ }^{4}$ Although non-ad valorem assessments come in many shapes and sizes, two types of assessments - Business Improvement Districts (BIDs) and Community Benefit Assessments (CBDs) - have attracted the most attention from scholars. For an overview of the literature, see Brooks (2006) on BIDs, and Baer and Marando (2001) on CBDs.
} 
Both of these strategies to limit redistribution are common in assessment districts in California. For example, landscape and lighting districts are generally drawn at a block-level, encompassing only a neighborhood or planned development. This funding strategy could also be used to support a specific school. For instance, in the outskirts of San Diego a combination of Mello-Roos districts entirely funded the construction of a new, state-of-the-art K-8 school, innovatively named "Design 39." Only those property owners who reside within the districts that funded the school are permitted to enroll their children, outraging other parents who live within a mile of that school but outside the boundaries of the pertinent assessment districts. ${ }^{5}$

Other localities have opted for the second strategy of limiting redistribution through flat (or flatter) funding mechanisms. Many cities in the bay area - Oakland, San Francisco, and Cupertino, for example - have passed flat parcel taxes to support their schools district-wide. For example, the city of San Francisco adopted a flat $\$ 198$ parcel tax to support teacher salaries. ${ }^{6}$ Similarly, the city of Davis assesses a flat fee, currently $\$ 99$ for single-family homes, to support its city's libraries. The assessment districts that employ this strategy are generally larger in geographic reach, encompassing an entire city or school district. They most commonly set aside taxes for a specific purpose, though there are exceptions. For example, the city of Fairfax uses parcel taxes to charge residents a flat $\$ 125$ per parcel for "General Purposes."

\footnotetext{
${ }^{5}$ http://www.kpbs.org/news/2014/jan/21/poway-unified-kids-cant-attend-new-school-because-/ as well as analysis of individual property tax records of residents of Poway's CFD \#6.

${ }^{6}$ The arguments against this special tax as they appeared on the official San Francisco voter information guide focused entirely on the distributional impact of this financing choice. As argued by Howard Epstein, the chairman of San Francisco's Republic Party, "The proponents of Proposition A had other options. Instead, they decided to place the burden on the City's small property owners. They could have asked for a sales tax increase, which would have fairly shared the burden among all San Francisco residents, businesses and visitors. They could have based the tax on square footage" (full text available at http://www.smartvoter.org/2008/06/03/ca/sf/meas/A/).
} 
Under what conditions will taxpayers prefer to create taxing or assessment districts rather than raise general taxes? While the nature of the public service surely plays an important role in this decision, we argue that the local social and economic context helps determine what financing mechanism individuals will prefer to use to finance local government. In turn, this decision helps define the population of residents who are allowed to enjoy the services provided by their municipalities or the progressivity of the financing mechanism used to support services.

In many ways, the decision to form a district instead of relying on general taxation represents a form of de facto - although not de jure - municipal secession. The same considerations that cause voters to form their own political jurisdictions should thus shape their preferred choice among available local financing options. Existing research has identified factors such as wealth and racial heterogeneity as the primary drivers of local government formation (see Miller 1981; Alesina, Baqir, and Hoxby 2004; Burns 1994; Musso 2001). Similarly, these same considerations are relevant to preferences for progressive taxation (Melzter and Richards 1981; Foster 2013). As such, we predict that the same socioeconomic conditions will explain patterns in the creation of assessment districts as well.

Our first hypothesis focuses on the economic status of California residents. We argue that the decision to pursue the creation of assessment districts hinges on the interests and motivation of higher-income taxpayers. Much as described by Miller (1981) for the decision to privatize or contract out public service when possible, well-off residents will prefer to finance public services through assessments rather than taxes. ${ }^{7}$ Using assessments allows wealthy taxpayers to limit the redistributive impact of local budgetary decisions either by ensuring that their contributions will be used to finance only public services in wealthy areas or with a flat

\footnotetext{
${ }^{7}$ Miller has argued that residents of richer cities substituted private insurance for fire service and contracted out police, library, and other municipal services.
} 
payment formula. In contrast, when the economic profile of local residents is relatively low income, taxpayers will have little reason to prefer assessment financing over general taxation. This logic of this prediction is rooted in the key insights from the canonical Meltzer and Richard (1981) model of redistribution that suggests that the income of the median voter is a pivotal determinant of redistribution, as well as well-established research findings that, as noted by Alesina and Giuliano, "the richer you are, the less you favor redistribution" $(2009,13)$.

Historically, there is strong evidence that assessments have been used to blunt redistributive spending within city governments. In her provocative study of nineteenth-century Chicago politics, Einhorn (1991) argues that assessment financing was used as a vehicle by wealthy property owners to limit service provision to low-income residents. "American city government in the nineteenth century," she writes, "worked on the principle that the distribution of services was equitable when each city dweller got what he paid for, no more and no less" $(1991,8)$. Einhorn shows that while services funded by general taxation, such as the sewer system, were provided to areas across the city, paved streets — funded through special assessments — were heavily concentrated in the wealthiest neighborhoods $(1991,141)$.

Second, recent work in the field of political economy has emphasized racial heterogeneity as a barrier to local public goods provision. Scholars have argued that ethnic diversity impedes the willingness of residents to tax themselves out of worry that the benefits of their investments will be captured by people much different than themselves, and diverted to policies they do not support (Alesina, Baqir, Easterly 1999; Alesina and Spolaore 1997; Easterly and Levine 1997; Glaser 2002; Habyarimana et al. 2007; Poterba 1994; Putnam 2007; Rugh and Trounstine 2011). In addition, Alesina, Baqir, and Hoxby (2004) show that racial heterogeneity 
has historically been associated with local government fragmentation within U.S. local government and has posed a major barrier to government consolidation.

For residents who prefer to support public services only if they benefit people who look like them but who reside in diverse municipalities, assessments represent an attractive solution. For example, white voters living on the outskirts of a large urban city may prefer higher levels of fire protection but be reluctant to increase citywide taxes for fear that their money will be used to subsidize other services provided to minority inner-city residents. By creating an assessment district, these voters can receive the services they desire while limiting the benefits provided to members of other ethnic groups living in other neighborhoods. In short, we expected higher levels of ethnic diversity to encourage greater reliance on assessment financing rather than citywide taxation.

\section{Data and Methods}

This paper seeks to identify the conditions under which taxpayers will prefer to use nonad valorem assessments to fund local public services. To answer this question, we looked for patterns in the frequency and use of non-ad valorem assessments across California, combining data from individual homes with aggregate data on community characteristics. This information was then used to test the hypotheses that economic wealth and ethnic diversity encourage greater reliance on assessment financing but not traditional taxation.

In particular, we are interested in comparing the factors correlated with non-ad valorem assessment financing to the factors associated with the use of general obligation bonds. As in most states, most property owners in California pay both types of charges through their property 
tax bills in addition to standard property taxes. ${ }^{8}$ The key differences between non-ad valorem assessments and general obligation bonds is: 1) the scope of their geographic reach, and / or 2) reliance on a tax rate contingent on property valuation; general obligation bonds are universally based on assessed property values and must be approved by the entire voting population of a city, county, or school district. We argue that non-ad valorem assessment use varies based on the wealth and the ethnic diversity of cities as a function of preferences to limit the redistributive nature of taxation and public service provision. This hypothesized pattern will occur more for assessments than bond obligations.

To explore the different foundations of ad valorem taxes versus non-ad valorem assessments it was necessary to collect itemized tax data for a set of individual properties. While tax data exists at various levels of aggregation, it is not finely itemized so that we can explore these differences. This will lead us, ultimately, to multi-level analysis.

We thus began our investigation by drawing a random sample of 1,000 California residential addresses using the California voter registration roll. ${ }^{9}$ From that sample, 675 property tax bills for the 2009-10 fiscal year were located by contacting local county tax collectors. Property tax records could not be located for the remaining observations, either because the property did not exist or because it was not a single-family home. The analysis was limited to single-family homes in order to estimate the distribution of burden for individual households. A large apartment complex has only a single tax bill and there is no way to calculate per-unit costs from this information.

\footnotetext{
${ }^{8}$ State law (Proposition 13) limits standard property taxes to one percent of assessed valuation. Since this prohibits local variation, these taxes are not considered in this analysis.

${ }^{9}$ Using voter registration rolls to draw the sample necessarily means that the sample will be skewed to adult, registered voters. Since this is the same population that is eligible to make decisions on local government infrastructure improvements, we view this bias as noncontentious.
} 
We coded each distinct charge that appears on the property tax bill. For a typical tax bill, this includes the base property tax obligation governed by Proposition 13 (one percent of assessed value), payments for voter-approved general obligation bonds, non-ad valorem assessments, and, on occasion, charges related to utility and sewer access. All utility and sewer charges were coded separately from assessments in order to ensure that the data was comparable across all counties. In some counties utility charges appear on separate water or utility bills instead of property tax bills, complicating direct comparisons.

In aggregate, our data collection efforts identified a total of $\$ 209,139$ in non-ad valorem assessments. This is similar to the amount of taxes paid through voter-approved bonds $(\$ 268,129)$ but significantly less than that paid by regular property taxes $(\$ 2,330,929)$. Individual non-ad valorem assessment charges ranged from small fees, such as a sixty-six-cent charge associated with a flood protection district in Yuba City, CA, to more significant items such as a levy of over $\$ 10,000$ used for maintaining landscaping and lighting in a neighborhood of multi-million dollar mansions in Orange County. ${ }^{10}$ The most common assessment charges were for the purposes of vector or flood control, though assessments fund a wide variety of public services such as schools, parks, libraries, and even emergency medical ambulances and public safety services.

Basic summary statistics for the dependent variables and all explanatory variables included in the analysis are reported in Table 1. The parcels in the sample comprise 38 unique counties and 227 unique census places. Among the 675 single-family homes in our sample, tax and assessment burdens of 614 parcels were analyzed. Nineteen parcels were eliminated from analysis because they were located in non-populous areas whose community characteristics

${ }^{10}$ This particular parcel was ultimately not used in the analysis due to its presence as an outlier. 
could not be quantified. An additional thirty-nine parcels were eliminated because no information was available on their property values or the year the home was built. Finally, an additional two parcels were removed due to their status as outliers. ${ }^{11}$ This leaves us with 614 observations.

Table 1: Descriptive Statistics

$\begin{array}{lccccc}\text { Variable (Units) } & \text { Obs } & \underline{\text { Mean }} & \underline{\text { Std. Dev. }} & \underline{\text { Min }} & \underline{\text { Max }} \\ \text { Non-Ad Valorem Assessments (\$) } & 614 & 235.87 & 455.34 & 0 & 5083.1 \\ \text { Bond Taxes (\$) } & 614 & 268.45 & 316.39 & 0 & 2414.57 \\ \text { Club Assessments (\$) } & 614 & 142.78 & 408.69 & 0 & 5074.18 \\ \text { Median Income (\$1,000s) } & 614 & 75.92 & 27.78 & 28.82 & 225.00 \\ \text { Ethnic Diversity } & 614 & 0.58 & 0.13 & 0.05 & 0.78 \\ \text { Zestimate (\$1,000s) } & 614 & 449.35 & 326.74 & 54 & 3305.50 \\ \text { Built Pre 1930 } & 614 & 0.06 & 0.24 & 0 & 1 \\ \text { Built 1930-1949 } & 614 & 0.09 & 0.29 & 0 & 1 \\ \text { Built 1950-1978 } & 614 & 0.45 & 0.50 & 0 & 1 \\ \text { Built 1979-2000 } & 614 & 0.29 & 0.46 & 0 & 1 \\ \text { Built Post-2000 } & 614 & 0.10 & 0.30 & 0 & 1 \\ \text { Population (10,000s) } & 614 & 38.12 & 82.99 & 0.18 & 379.68 \\ \text { Population Density (1,000s/sq mile) } & 614 & 5.07 & 3.33 & 0.05 & 20.07\end{array}$

Information gathered from individual property tax bills was supplemented with data from the Census Bureau and Zillow Inc. to gain additional information about the parcels and their surrounding areas. These additional variables controlled for other factors that affect financing choices and additional parcel-to-parcel variation.

We chose to measure many of our independent variables at the level of the census place using five-year estimates from the American Community Survey dataset (2005-2009). Census places are roughly equivalent to cities, both incorporated and unincorporated. In our sample, census places range from populations of 407 (Westly, CA) to almost 4 million (Los Angeles, CA). City-level variables are important to the analysis because decisions to approve bonds or

${ }^{11}$ We choose to winsorize the dataset, excluding these two outliers who had home values of over $\$ 7$ million dollars. Results without these omitted parcels are available as supplementary material. 
otherwise raise general government revenues will often reflect considerations at the city level. For this reason both of the key variables (ethnic heterogeneity and median income) as well as control variables (population and population density) were measured at this level of analysis.

The measure of city wealth was operationalized as median family income. We focused on the median member of a community as a proxy for the income of a median voter ${ }^{12}$. We theorized that median family income would be positively associated with the usage of non-ad valorem assessments since, all else equal, a wealthy median voter would be less likely to favor redistributive taxation (Alesina and Giuliano 2009). We do not expect the same relationship for general obligations bonds, as they are relatively more redistributive. Table 2 displays mean assessment and bond taxes by quintiles of city median income, providing preliminary support for our hypothesis that city wealth uniquely explains assessment financing.

Our second hypothesis concerns racial and ethnic diversity. To measure this we use the Herfindahl index of ethnic diversity. A Herfindahl index is a statistical representation of the relative concentrations of firms or groups on a scale of zero to one. It was first used by economists to gauge the size of firms within industries to identify monopolies, but has been subsequently used by social scientists as a measure of ethnic diversity (Alesina, Baqir, and Easterly 2007). The Herfindahl index is calculated using the relative size of different ethnic

\footnotetext{
${ }^{12}$ We recognize that the median voter may not be the pivotal actor in taxation and assessment decisions. Many assessments require two-thirds approval and/or require the vote or property owners, not registered voters. We justify this operationalization both with the ubiquity of the median voter theorem's application in poltical decision making, as well as the recognition that median family income would be highly correlated with the level income at other percentiles. We also recognize that the median of the income distribution might not be the median wealth of the voting distribution. As long as income and wealth are determined by some underlying charecteristics however, and as long as property owners are eligible to vote, this measure should be adequately represent our idealized construct.
} 
groups according to census estimates. ${ }^{13}$ An area is coded as one on the Herfindahl index if it is composed entirely of a single ethnic group, while a number closer to zero represents high levels of ethnic diversity. To ease interpretation, this coding was reversed so that high numbers represent higher levels of diversity. We expected that higher levels of diversity would be associated with higher levels of assessments. Table 2 also displays the mean assessments and bond taxes for our sample by quintiles of city ethnic diversity, providing preliminary support for our hypothesis that racial differences uniquely explain assessment financing, not bond financing.

In addition to city-level data, we are able to measure and control for two important variables at the individual level of the individual parcel. Specifically, data from Zillow Inc. was used to achieve a more-precise estimate of the market value for each parcel as well as the year that the individual property was built. Zillow publishes monthly estimates of home values known as "Zestimates". Zestimates are computed using a proprietary formula based on house attributes, neighborhood attributes, and nearby real-estate transactions. ${ }^{14}$ Estimates computed for August 1, 2010 were employed. We theorized that more expensive homes would have greater assessment burdens. Since bond obligations are calculated based on assessed value, which is correlated with market value, we also expected a positive correlation between individual home value and bond taxes. Table 2, using quintiles of Zestimates, also confirms these expectations, as well as the expectation that assessments will be less progressive than bond taxes.

\footnotetext{
${ }^{13}$ The path in creating any index is to take something that is multidimensional and to measure it with a unidimensional variable. This is arguably fine as long as we can think of the construct of diversity as a single dimension.

${ }^{14}$ More information about the computation of Zestimates is available at http://www.zillow.com/zestimate/.
} 
Table 2. Mean Non-Ad Valorem Assesments and Bond Taxes by Variable Quintiles

\begin{tabular}{|c|c|c|}
\hline & Assessments & Bond Taxes \\
\hline City Income Q1 & $\$ 140.14$ & $\$ 314.93$ \\
\hline City Income Q2 & $\$ 202.49$ & $\$ 193.06$ \\
\hline City Income Q3 & $\$ 206.77$ & $\$ 206.96$ \\
\hline City Income Q4 & $\$ 305.64$ & $\$ 323.18$ \\
\hline City Income Q5 & $\$ 315.55$ & $\$ 303.54$ \\
\hline
\end{tabular}

$\begin{array}{lcc} & \text { Assessments } & \text { Bond Taxes } \\ \text { City Diversity Q1 } & \$ 179.87 & \$ 243.75 \\ \text { City Diversity Q2 } & \$ 194.69 & \$ 277.04 \\ \text { City Diversity Q3 } & \$ 176.77 & \$ 198.98 \\ \text { City Diversity Q4 } & \$ 298.34 & \$ 313.44 \\ \text { City Diversity Q5 } & \$ 327.24 & \$ 310.65\end{array}$

$\begin{array}{lcc} & \text { Assessments } & \text { Bond Taxes } \\ \text { Home Value Q1 } & \$ 109.09 & \$ 109.92 \\ \text { Home Value Q2 } & \$ 252.90 & \$ 170.18 \\ \text { Home Value Q3 } & \$ 224.33 & \$ 284.90 \\ \text { Home Value Q4 } & \$ 207.18 & \$ 313.31 \\ \text { Home Value Q5 } & \$ 376.56 & \$ 464.44\end{array}$

\begin{tabular}{lccc} 
& Assessments & Bond Taxes \\
\cline { 2 - 3 } Year Home Built Q1 & $\$ 222.53$ & $\$ 302.86$ \\
Year Home Built Q2 & $\$ 113.77$ & $\$ 255.21$ \\
Year Home Built Q3 & $\$ 92.91$ & $\$ 256.86$ \\
Year Home Built Q4 & $\$ 154.41$ & $\$ 246.10$ \\
Year Home Built Q5 & $\$ 584.99$ & $\$ 275.97$
\end{tabular}

Zillow also provides public information on the year each home was built. The age of local housing stock should also play an important role in determining the number of special charges assessed by local governments. Many of the statutes governing the creation of assessment districts were adopted following Proposition 13 in 1978, and generally made it easier to impose assessments on newly built rather than existing housing units (see Kogan and McCubbins' 2008 discussion of Mello-Roos districts). As a result, newer homes tend to have 
higher reliance on assessment financing than older homes because the transaction costs of district formation are substantially lower in newer versus older neighborhoods (Baer and Feiock 2005). Table 2 also shows both mean assessments and bond taxes by quintiles of year built, confirming our expectations that the age of the home is uniquely related to assessments. To capture the interaction of legal and economic changes on the propensity of homes of different ages to carry assessments, we transform age into a series of dummy variables, demarcating pre-1930, 1930$1949,1950-1978,1979-2000$, and 2001-2010. The first two categories roughly demonstrate the pre-Great Depression, with the second demonstrating the Great Depression and World War II eras, the third captures the post-war growth period prior to Proposition 13, while the last two time periods are demarcated by Proposition 13 (1978) and Proposition 39 (2000). ${ }^{15}$

In we show how these age cutoffs affect non-ad valorem assessments (excluding utility charges). As expected these assessments were higher on homes built prior to the Great Depression. Assessment districts, due to defaults, fell out of favor during the Great Depression, explaining the decline in their use for the next two periods. The biggest changes can be seen in the post tax-revolt periods.

\footnotetext{
${ }^{15}$ Proposition 13 (1978) along with other things, limted ad-valorem tax on real property to $1 \%$ of full cash value. It also required a two-thirds vote majority to increase local special property taxes. Proposition 39 (2000) lowered the required supermajority necessary for voters to impose taxes to pay for school bonds from two-thirds majority to fifty-five percent. Proposition 218, though not demarcated is alos relevant. Enacted in November 1996, this proposition affected finance for nearly 7,000 city, county, special districts, schools, community college districts, redevelopment agencies, and regional organization in California.
} 
Figure 1: Non-Ad Valorem Assessments by Year Home Built

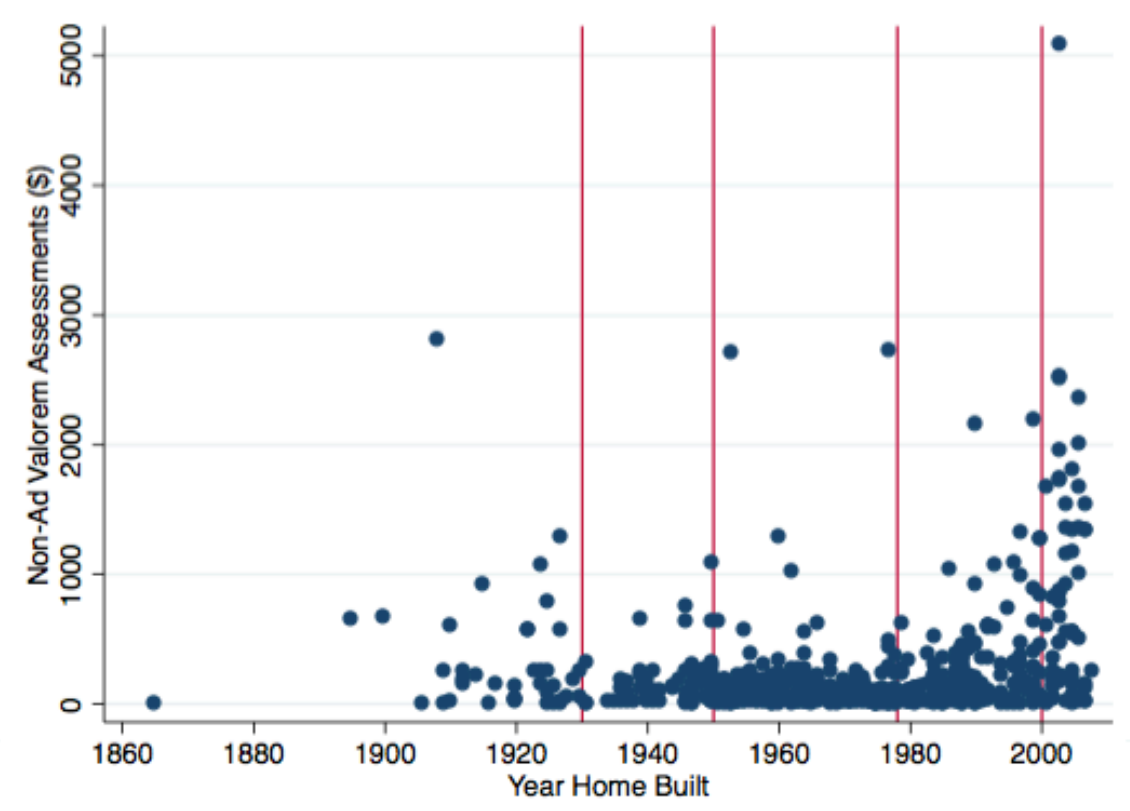

Regression analysis was used to identify the correlates of non-ad valorem assessments.

The occurrence of assessments was predicted by using city-level ethnic diversity and income. In the regression analysis, we also controlled for a city's population and population density. The key predictions were that assessments would be more prevalent in areas with high levels of ethnic diversity and wealth. Separate Poisson regressions were used to predict the total amount collected through non-ad valorem assessments versus bonds levied on each property. Poisson estimation is appropriate because assessments and bond payments are always non-negative and sometimes zero. Calculating the mean squared error out of sample for half of the data validated this choice; Poisson estimation had a lower mean squared error than models that employed OLS, Tobit, or GLM with a log-link.

As noted, the variables employed are at multiple levels of analysis. The dependent variables and two explanatory variables (home value and year built) were measured at the parcel level. The other variables, derived from census estimates, exist at the level of a census place. 
Although the sample was drawn randomly, random selection alone does not imply independence. Indeed, we theorized that two parcels in the same city would be more alike, likely in unobservable and unmeasured ways, than two parcels in different geographical areas. This unobserved correlation violates the Gauss-Markov assumption of independence of errors. Because positive correlation in the error terms was expected, ignoring this issue could lead to a type 1 error (incorrectly rejecting the null hypothesis). As such, all models employ clustered standard errors by census place.

\section{Results}

The results of the Poisson regression estimation appear in Table 3. The first model presents the results for non-ad valorem assessments while the second model presents the results for general obligation bonds. The dependent variable in both models is the total amount of money owed for these items by a homeowner on their property tax bill. The comparative results are useful because they show that these different forms of public financing have systematically distinct origins.

A city's median family income was a significant predictor of both assessments and, to a lesser extent (significance $<$ p.10) and contrary to our expectations, general obligation bonds. ${ }^{16}$ The finding for assessments is consistent with our hypothesis that well-off residents — in particular a relatively well-off median voter — will prefer to finance public services through assessments rather than taxes. Figure 2 displays the predicted level of assessments and bonds relative to changes on income from the $10^{\text {th }}$ to $90^{\text {th }}$ percentiles. For example, moving from the

\footnotetext{
${ }^{16}$ Why might general obligation bonds be positively associated with high median incomes? In some ways, this runs contrary to predictions from the Meltzer-Richard model. It may be that communities with high incomes see their community as relatively homogeneous and thus do not consider all bonds to be redistributive. Regardless of this relationship, it is still noteworthy that income has a much greater marginal effect on non-ad valorem assessments than bond financing.
} 
$25^{\text {th }}$ percentile $(\$ 56,000)$ to $75^{\text {th }}$ percentile $(\$ 88,000)$ of city median family income was associated with a $\$ 81$ increase in non-ad valorem assessments, all else equal. In contrast, the relationship between median income and bond taxes was weaker (and only significant at the $10 \%$ level), a $\$ 34$ marginal effect between the $25^{\text {th }}$ to $75^{\text {th }}$ percentiles. Because median family income was measured at the city level, these results must be interpreted as averages among citizens within a city. It is possible, as we will explore in greater depth later, than averages conceal important differences at an individual level.

Table 3: Poisson Regression Analysis of Non-Ad Valorem Assessments and Bonds

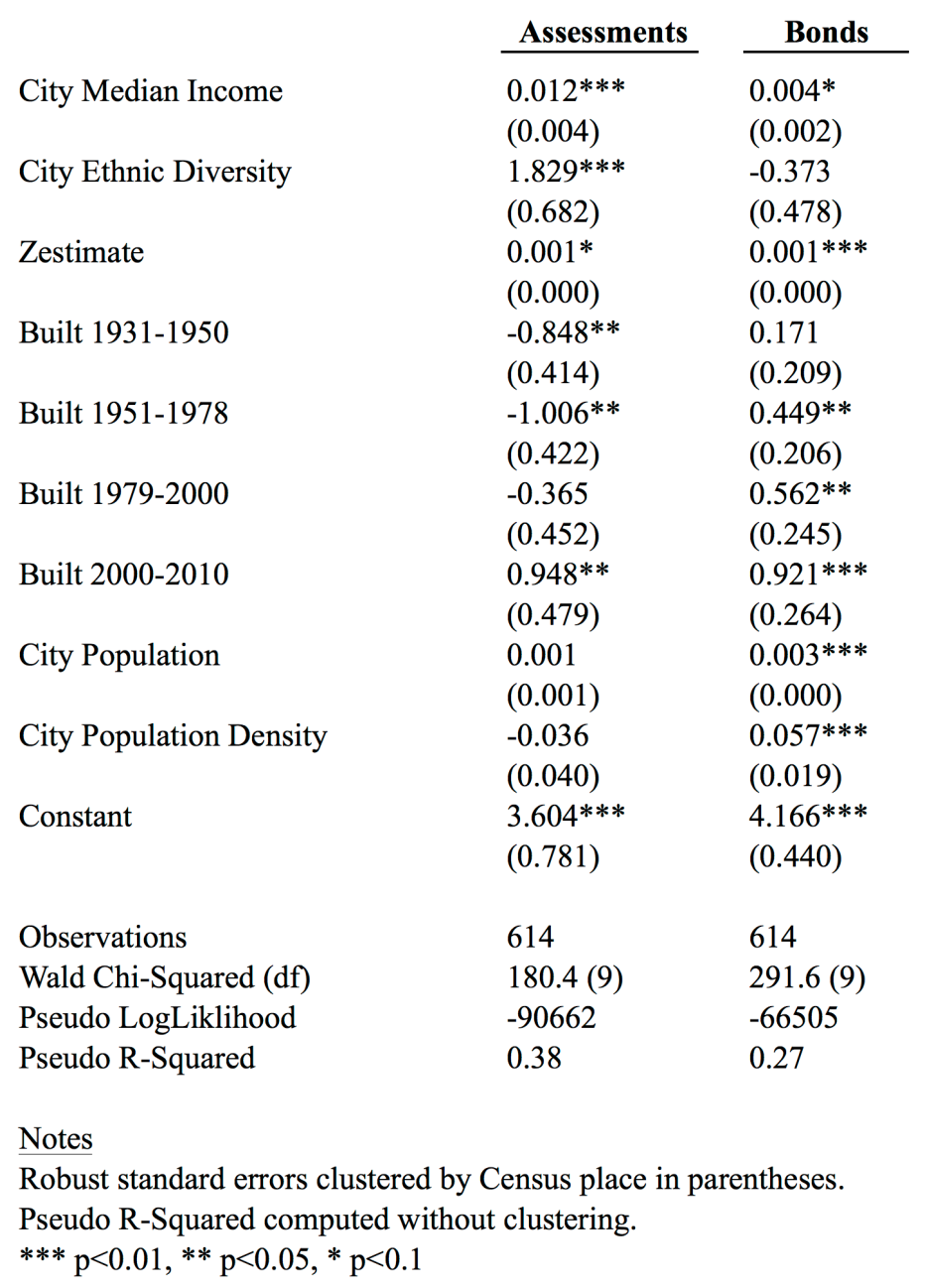




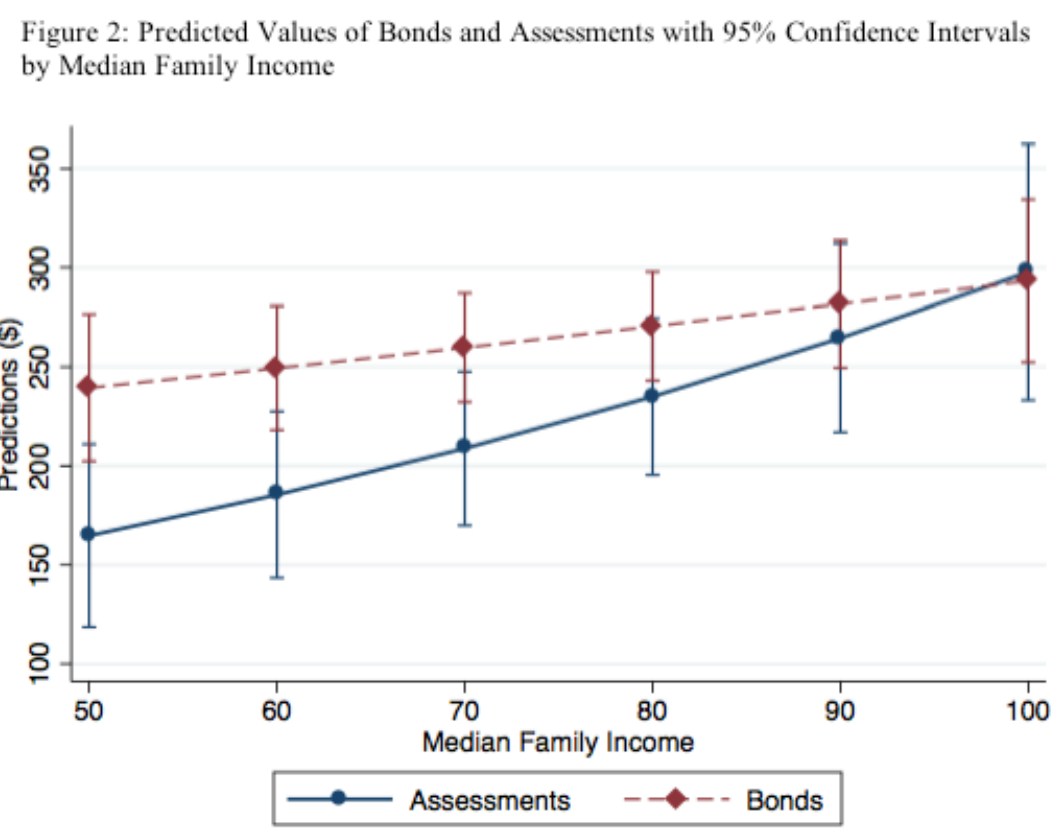

The second hypothesis that non-ad valorem assessments are more common in areas of high ethnic diversity was also confirmed. Figure 3 displays the predicted values across the minimum and maximum values of this variable. For example, moving from $25^{\text {th }}$ percentile $(0.5)$ to the $75^{\text {th }}$ percentile $(0.68)$ in this index was associated with a $\$ 79$ difference owed to non-ad valorem assessments, all else equal. Again, this must be construed as the average effect for all members of a city. There is no corresponding association between city diversity and bond taxes and, indeed, the insignificant coefficient was negative in sign. Ethnic diversity was not related to taxes for bond obligations. 


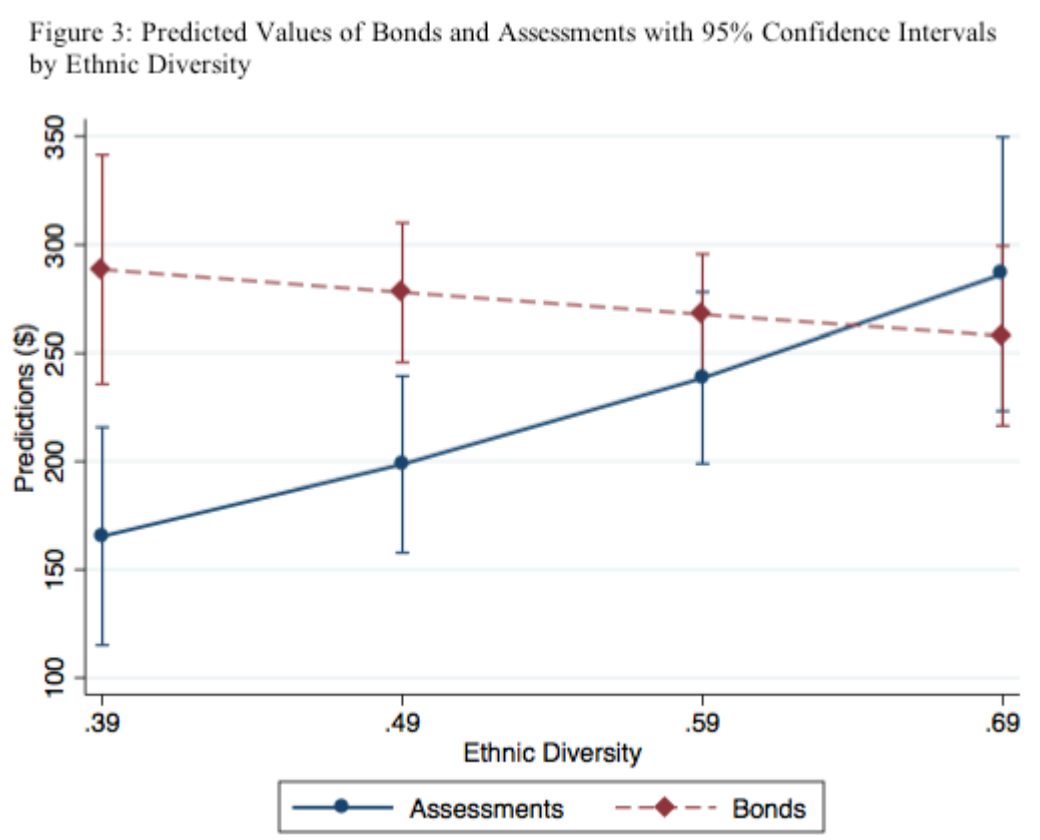

The covariates in the model behaved as expected. Non-ad valorem assessments were positively and significantly associated with the year the home was built, particularly in the PostProposition 39 era. This supports anecdotal evidence that developers who are unable to use property taxes to fund the necessary infrastructure and public services for their housing projects often create assessment districts. Homes built after 2000 were assessed on average $\$ 834$ in nonad valorem assessments, compared to under $\$ 150$ for homes built between 1930 and 1978, and \$225 for homes built between 1979 and 2000. The oldest homes in our dataset were also assessed at higher levels, averaging $\$ 324$, but with wide confidence intervals. The results are displayed visually in Figure 4. The findings contrast markedly with bond taxes (Figure 5), which increase monotonically with year home built, perhaps a consequence of the fact that, as a result of Proposition 13, the assessed value of newer homes is closer to market value than older homes. 

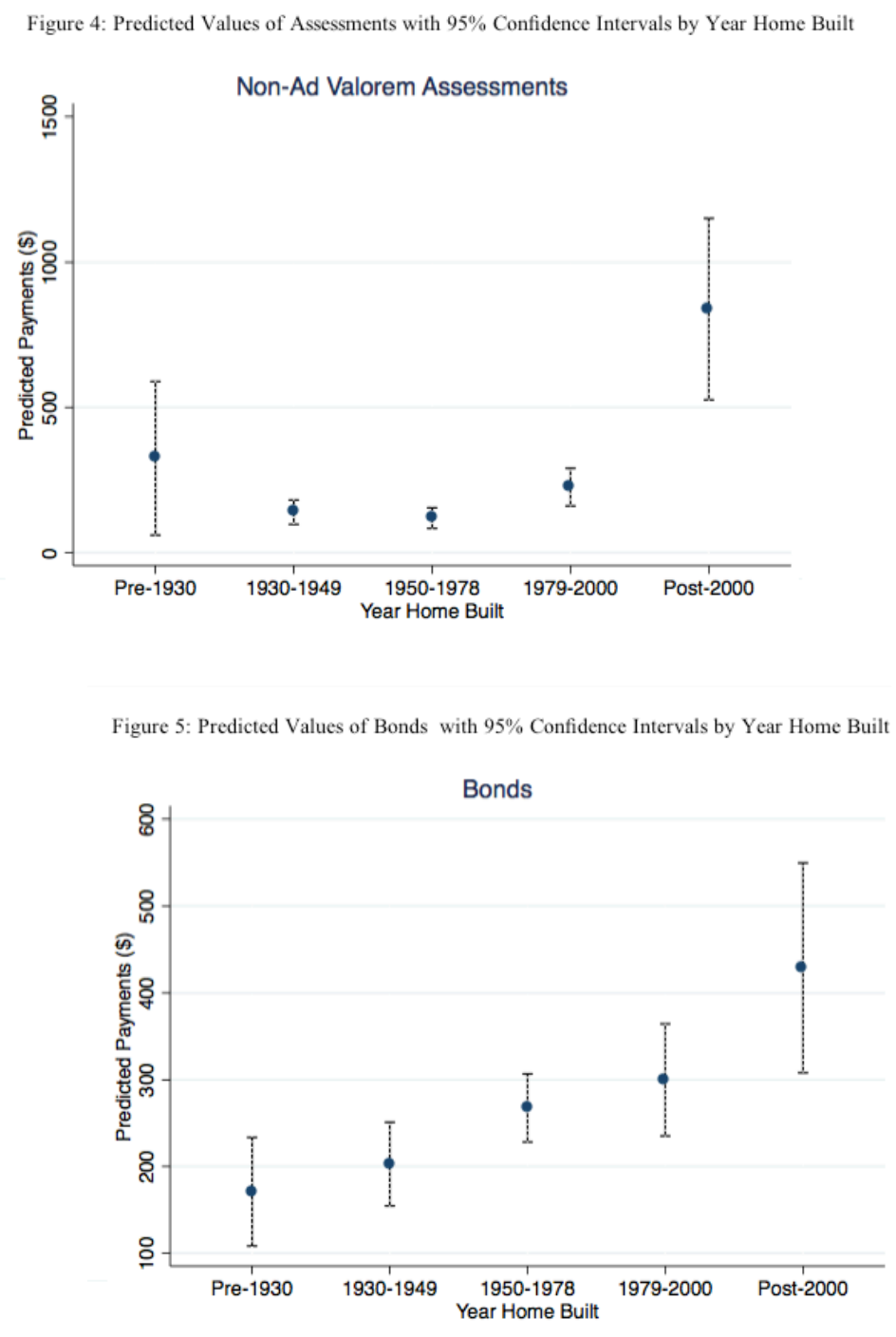

Non-ad valorem assessments were not associated with larger and denser cities. The coefficients for the two variables measuring both population characteristics were all insignificant in the model for assessments, but positive and significant correlates of bond obligations. This fits with the importance of new developments in the issuance of assessments, given that morepopulous and dense communities are more likely to be long-established communities.

Finally, individual home value as measured by Zestimate predicted both assessments and bonds, though assessments only at the $10 \%$ level of significance. Moving from the $25^{\text {th }}$ $(\$ 232,000)$ to the $75^{\text {th }}(\$ 574,000)$ percentile in this variable was associated with a $\$ 41$ change in 
assessments and a $\$ 63$ change in bond obligations. The larger coefficient and greater significance for this variable on bond taxes aligns with the expectation that bond taxes are be relatively more progressive than assessments.

\section{Within City Variation: An Analysis of "Club" Assessments}

We have shown that city level characteristics are strongly associated with the usage of non-ad valorem assessment. In addition to this overall correlation, we expect that intra-city dynamics affect the allocation of assessments at a more micro-level. Recall, assessment do not need to be levied by pre-existing forms of governments (cities, counties, or school districts). Indeed, it is common for assessment districts to be drawn at a neighborhood level.

To better explore these dynamics, we recode our dependent variable to exclusively capture assessments that are smaller than existing government boundaries (generally, cityboundaries, though potentially school district boundaries in the case of single-school levies) ${ }^{17}$. We deem these types of assessments "club" assessments, a reference to the economic literature on "club goods", public goods that are non-rival but excludable. Here, the drawing of district lines within existing government boundaries define excludability.

To recode our dependent variable we individually examined all charges that appeared on property tax bills, summing only those that could be categorized as club assessments. Assessment charges on property tax bills always include descriptions of their purpose. It was sometimes possible to code the geographic scope of the assessment district from this information alone. For example, landscape and lighting assessments differentiated by "zones" are indicative

\footnotetext{
${ }^{17}$ We exclude assessments that are larger than the scope of a single city. Generally, these types of assessments - common for fire our misquito abatement - are used to secure decreasing marginal costs of service provision, not to limit the redistribution of public services.
} 
of club assessments. Often, however, it was necessary to evaluate additional public documents to correctly code geographic scope. Districts formed to assess Mello-Roos taxes, for example, can either encompass mere blocks or entire cities. In these instances, public records, for example maps of assessment districts or the full-text of the districts adoption by ballot measure, were obtained to ensure accurate coding.

Club assessments account for $61 \%$ of all non ad-valorem assessments analyzed in this paper, or $\$ 142$ on average per single-family home. Although we maintain that overall assessment financing is used more in wealthier communities, we also expect wealthy residents of poorer communities to utilize this public service financing option at significant levels. This form of assessment allows property owners to limit redistribution by defining a limited geographic scope of the public services provided.

To test for differential effects in rich and poor communities, we split our model in half, analyzing cities whose median family incomes is above and below the sample median $(\$ 72,600)$ separately. Table 4 provides our analysis of club assessments. Our findings are robust to the alternative model specification of a multiplicative interaction effect (results available in appendix table A1). We prefer the split model as it allows all variables in the model to interact with city wealth. We maintain the variable for median family income as a control, that it is insignificant across most models validates the decision to cut the sample at the median. 
Table 4: Poisson Regression Analysis of Club Assessments and Bonds by City Income

\begin{tabular}{lll|ll} 
& \multicolumn{2}{c|}{ Poor Cities } & \multicolumn{2}{c}{ Wealthy Cities } \\
& $\begin{array}{c}\text { Club } \\
\text { Assessments }\end{array}$ & \multicolumn{1}{c}{ Bonds } & Club \\
& & & \\
& & & \\
& & & \\
Assessments & Bonds \\
City Median Income & -0.01 & -0.008 & 0.011 & $0.008^{*}$ \\
& $(0.021)$ & $(0.011)$ & $(0.009)$ & $(0.004)$ \\
City Ethnic Diversity & $2.668^{* * *}$ & 0.301 & $2.699^{* *}$ & -0.436 \\
& $(0.994)$ & $(0.655)$ & $(1.174)$ & $(0.933)$ \\
Zestimate & $0.002^{* * *}$ & $0.002^{* * *}$ & 0.000 & $0.001^{* * *}$ \\
& $(0.000)$ & $(0.000)$ & $(0.000)$ & $(0.000)$ \\
Built 1931-1950 & -0.195 & $0.786^{* * *}$ & $-1.774^{*}$ & -0.022 \\
& $(0.500)$ & $(0.294)$ & $(1.049)$ & $(0.195)$ \\
Built 1951-1978 & -0.164 & $0.697^{* *}$ & -1.434 & 0.357 \\
& $(0.419)$ & $(0.324)$ & $(1.229)$ & $(0.307)$ \\
Built 1979-2000 & 0.087 & $0.992^{* * *}$ & 1.173 & 0.411 \\
& $(0.387)$ & $(0.371)$ & $(1.346)$ & $(0.358)$ \\
Built 2000-2010 & $2.557^{* * *}$ & $1.506^{* * *}$ & $2.459^{*}$ & $0.709^{*}$ \\
& $(0.447)$ & $(0.375)$ & $(1.374)$ & $(0.403)$ \\
City Population & 0.001 & $0.002^{* * *}$ & $0.007^{* *}$ & $0.005^{* *}$ \\
& $(0.001)$ & $(0.000)$ & $(0.003)$ & $(0.002)$ \\
City Population Density & $-0.100^{*}$ & $0.057^{* *}$ & -0.094 & $0.052^{* *}$ \\
& $(0.060)$ & $(0.025)$ & $(0.109)$ & $(0.024)$ \\
Constant & $2.582^{*}$ & $3.837^{* * *}$ & 1.846 & $3.996^{* * *}$ \\
& $(1.358)$ & $(0.541)$ & $(2.068)$ & $(0.924)$ \\
Observations & & & & \\
Wald Chi Squared (df) & 305 & 305 & 304 & 304 \\
Pseudo LogLiklihood & $390.7(9)$ & $639.9(9)$ & $191.4(9)$ & $113(9)$ \\
Pseudo R-Squared & -21808 & -22428 & -41591 & -40685 \\
& 0.57 & 0.42 & 0.54 & 0.2 \\
& & & &
\end{tabular}

Notes

Robust standard errors clustered by Census place in parentheses.

Pseudo R-Squared computed without clustering.

$* * * \mathrm{p}<0.01,{ }^{* *} \mathrm{p}<0.05,{ }^{*} \mathrm{p}<0.1$

Many of the dynamics reported earlier are consistent in the split model of club assessments. In particular, the effect of ethnic diversity is consistent. Regardless of community wealth, increases in ethnic diversity increase the usage of club assessments. For example, moving from the $25^{\text {th }}$ to the $75^{\text {th }}$ percentiles of the full sample would increase assessments by $\$ 50$ 
in poorer communities and $\$ 83$ in wealthy communities. Likewise, the effect of new construction is consistent as well. In poorer communities, post-1996 construction stands out exclusively. Whereas the expected value of club-assessments is roughly $\$ 50$ for all other eras, homes built after 2000 are charged $\$ 704$ in club assessments on average. In wealthier communities, there is significantly more temporal variability (with full predicted values displayed in figures 6 and 7), but once again post-1996 built homes clearly stand out, averaging $\$ 838$ in club assessments.

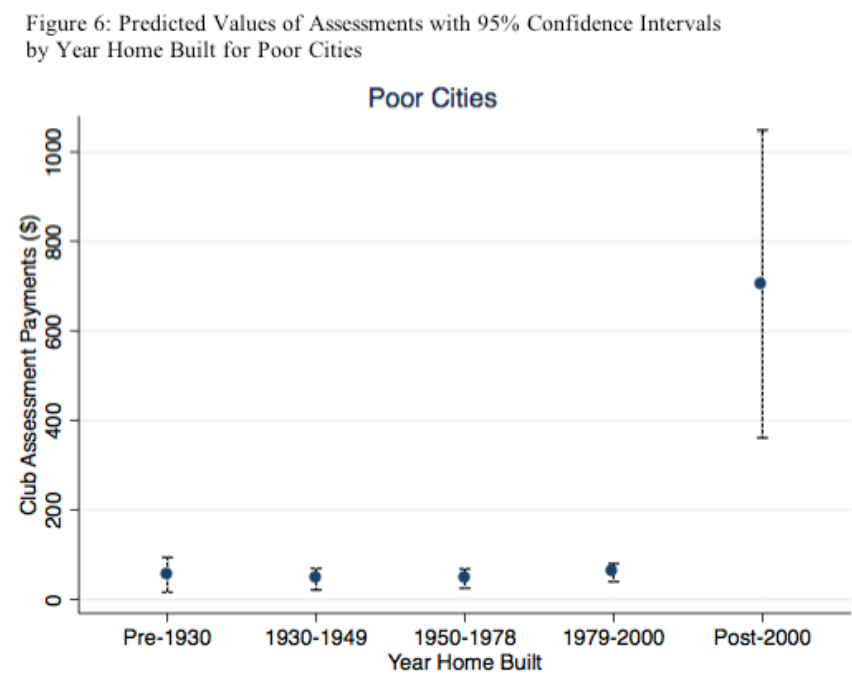

Figure 7: Predicted Values of Assessments with 95\% Confidence Intervals by Year Home Built for Rich Cities

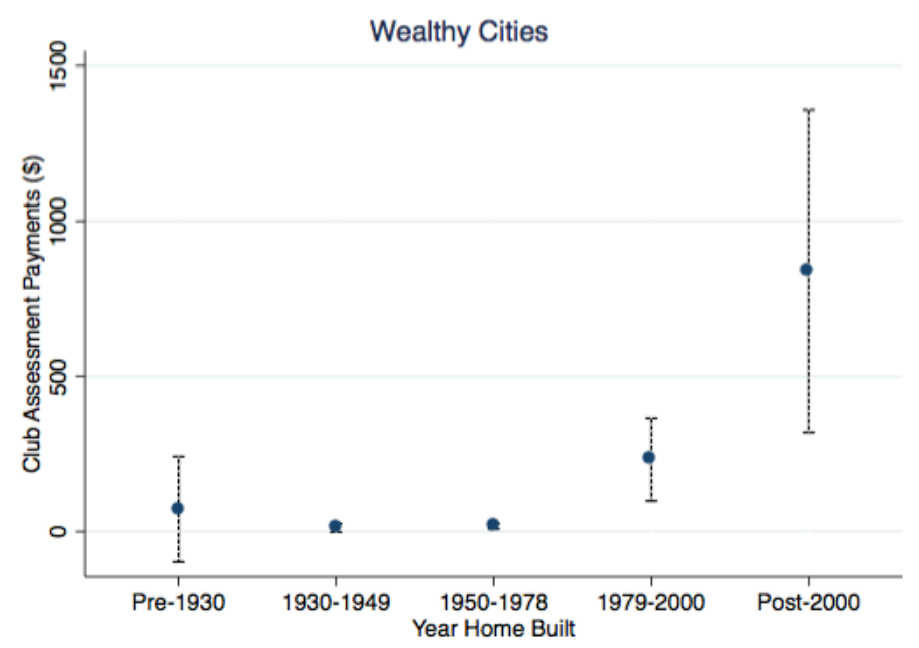


Our primary estimation showed a strong relationship between home value and both assessments and bond obligations. In the split model, our findings diverge. In particular, home value is an important determinant of assessments in cities with below median incomes, but not in wealthier places. This finding of equality in wealthy communities (roughly $\$ 180$ per household regardless of property value) may be because all homeowners are simply more likely to approve of assessment financing in wealthy cities, or because the assessments are more likely to be calculated flatly in these areas. Our data cannot differentiate these explanations.

In contrast, home value is an extremely important determinant of assessment financing in cities with below median median income. Here, we find that moving from the $25^{\text {th }}$ to the $75^{\text {th }}$ percentile would increase assessments from $\$ 92$ to $\$ 198$. In other words, expensive homes in poor communities have more club assessment a home of any value in wealthier communities. This finding is likely in line with our theory of assessments, that their limited geographic scope is used to blunt redistribution to poorer neighbors. These findings are displayed visually in Figure 8.

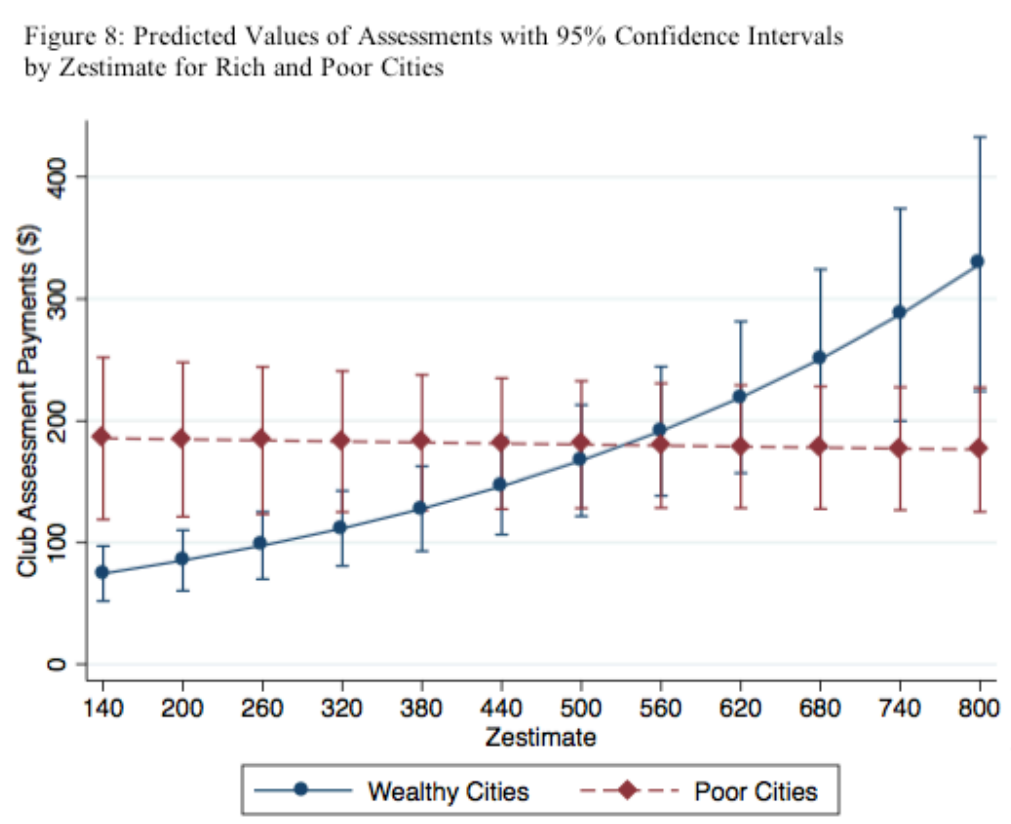


In contrast, home value operates similarly in poor and rich cities for general obligation bonds. In both types of city, the effect of home value is positive and significant. In terms of marginal effects, moving from the $25^{\text {th }}$ to $75^{\text {th }}$ percentiles increases bond obligations from $\$ 192$ to $\$ 333$ in poor cities and $\$ 224$ to $\$ 277$ in wealthy cities. We do not offer any explanation for the larger marginal effect in poorer cities.

\section{Conclusion}

Rising inequality has represented one of the most salient economic and political developments in the second half of the twentieth century (Bartels 2008; Hacker and Pierson 2010). The growing gap between haves and have-nots has also had an important spatial dimension. Geographic sorting, best exemplified by white flight to the suburbs that was accelerated by the federal government's promotion of homeownership and the construction of the interstate highway system, has remade U.S. political geography and created interregional disparities in the level of public-service provision (e.g., Dreier, Mollenkopf, and Swanstrom 2004; Musso 2001; Nall 2012). This has shown how recent innovations in public financing have also contributed to socioeconomic balkanization, not only between but also within U.S. cities.

Overall, the results presented in this paper provide some initial evidence that how local governments are financed has important implications for who gets to take advantage of the services that these agencies provide. The findings show that efforts to limit property taxes and the resulting innovations in public finance that these limitations engender — have affected not only how much revenue local governments can raise but also the identity of the constituents who pay and to whom services are delivered. Our results suggest that in areas of wealth and high ethnic diversity, non-ad valorem assessments allow taxpayers to restrict access to public 
services and progressivity of taxation.

Of course, limiting redistribution may have been one of the original motivations for the tax revolt. Some scholars have suggested that in California Proposition 13 may have had its roots in a series of state Supreme Court decisions in the 1970s that found local inequality in public school financing to be unconstitutional and ordered the state to take steps to equalize the resources available to school districts. These decisions broke the link between the level of property taxes raised by local governments and the amount of money available to local schools. Proposition 13 passed just as the state legislature had begun to take steps to implement the court's decisions. The ability to use non-ad valorem assessments to create hyperlocal service provision may be one reason voters rejected a second constitutional amendment in the 1980s, promoted by one of the original authors of Proposition 13, that sought to include assessments in the property tax limitation adopted in 1978 (Kogan and McCubbins 1986).

We conclude with a word of caution about indicting non-ad valorem assessment financing on the grounds that it perpetuates or exacerbates existing social and economic inequality. Throughout this work we assumed that the only two choices available to taxpayers were financing local services through higher taxes or by creating assessment districts. Of course, other options are available: to move out of their city, or to secede and incorporate as a separate municipality. Indeed, historical evidence suggests that the desire to avoid the high taxes of the inner city represents one of the main drivers of suburban incorporation (see, e.g., Miller 1981; Burns 1994; Hoene, Baldassare, and Shires 2002). To the extent that assessments allow struggling inner cities to "keep their suburbs" (Rusk 2003) by providing a viable alternative to relocation and separate incorporation, they may be better than the alternatives, despite their democratic flaws. 


\section{References}

Alesina, Alberto, Reza Baqir, and William Easterly 1999. "Public Goods and Ethnic Divisions." Quarterly Journal of Economics 114 (4): 1243-84.

Alesina, Alberto, Reza Baqir, and Caroline Hoxby. 2004. "Political Jurisdictions in Heterogeneous Communities.” Journal of Political Economy 112 (2): 348-95.

Alesina, Alberto and Paola Giuliano. 2009. "Preferences for Redistribution.” No. W14825. National Bureau of Economic Research, Cambridge, MA.

Alesina, Alberto and E. Spolare. 1997. "On the Number and Size of Nations." Quarterly Journal of Economics 112: 1027-56.

Baer, Susan E. and Richard C. Feiock. 2005. "Private Governments in Urban Areas: Political Contracting and Collective Action.” American Review of Public Administration 35 (1): $42-56$.

Baer, Susan E. and Vincent L. Marando. 2001. "The Subdistricting of Cities: Applying the Polycentric Model.” Urban Affairs Review 36 (5): 721-33.

Bartels, Larry M. 2008. Unequal Democracy: The Political Economy of the New Gilded Age. Princeton, NJ: Princeton University Press.

Brooks, Leah. 2006. "Does Spatial Variation in Heterogeneity Matter? Assessing the Adoption of Business Improvement Districts.” Review of Policy Research 23 (6): 1219-33.

Burns, Nancy. 1994. The Formation of American Local Government. Oxford: Oxford University Press.

California Legislative Analyst's Office. 2012. “Understanding California's Property Taxes”. Available at http://www.lao.ca.gov/reports/2012/tax/property-tax-primer-112912.aspx 
Chapman, Jeffrey I. 1998. Proposition 13: Some Unintended Consequences. San Francisco, CA: Public Policy Institute of California.

County of Fresno v. Malmstrom. 1979. 94 Cal App. 3d 974.

Dreier, Peter, John Mollenkopf, and Todd Swanstrom. 2004. Place Matters: Metropolitics for the Twenty-First Century. Lawrence: University Press of Kansas.

Easterly, William and R. Levine. 1997. “Africa’s Growth Tragedy: Politics and Ethnic Divisions." Quarterly Journal of Economics 112: 1203-50.

Einhorn, Robin. 1991. Property Rules: Political Economy in Chicago, 1833-1872. Chicago, IL: University of Chicago Press.

Foster, John M. 2013. "Voter Ideology, Economic Factors, and State and Local Tax Progressivity.” Public Finance Review 41 (2): 177-202.

Glaser, James M. 2002. "White Voters, Black Schools: Structuring Racial Choices with a Checklist Ballot," American Journal of Political Science 46 (1): 35-46.

Hacker, Jacob S. and Paul Pierson. 2010. Winner-Take-All Politics: How Washington Made the Rich Richer-and Turned Its Back on the Middle Class. New York: Simon \& Schuster.

Hoene, Christopher, Mark Baldassare, and Michael Shires. 2002. "The Development of Counties as Municipal Governments: A Case Study of Los Angeles County in the Twenty-First Century." Urban Affairs Review 37 (4): 575-91.

Habyarimana, James, Macartan Humphreys, Daniel Posner, and Jeremy Weinstein. 2007. “Why Does Ethnic Diversity Undermine Public Goods Provision?” American Political Science Review 101 (4): 709-25. 
Kogan, Vladimir and Mathew D. McCubbins. 2008. "The Problem With Being Special:

Democratic Values and Special Assessments.” Public Works Management and Policy 14 (1): 4-36.

Land, Alan E. 1967. "Toward Optimal Land Use: Property Tax Policy and Land Use Planning.” California Law Review 55 (3): 856-97.

Meltzer, Alan H. and Scott F. Richard. 1981. "A Rational Theory of the Size of Government." Journal of Political Economy 89 (5): 914-27.

Misczynski, Dean J. 1978. "Special Assessments.” In Windfalls for Wipeouts: Land Value Capture and Compensation, edited by Donald G. Hagman and Dean J. Misczynski. Chicago, IL: American Society of Planning Officials.

Martin, Isaac William. 2008. The Permanent Tax Revolt: How the Property Tax Transformed American Politics. Stanford, CA: Stanford University Press.

Mikesell, John. 2010. Fiscal Administration: Analysis and Applications for the Public Sector, 8th edition. Belmont, CA: Wadsworth Publishers.

Miller, Gary J. 1981. Cities by Contract: The Politics of Municipal Incorporation. Cambridge, MA: MIT Press.

Moule, Ellen and Nicholas Weller. 2012. "Diffusion in Direct Democracy The Effect of Political Information on Proposals for Tax and Expenditure Limits in the U.S. States.” States Politics and Policy Quarterly 11 (3): 348-368.

Mullins, Daniel R., and Philip G. Joyce. 1996. "Tax and Expenditure Limitations and State and Local Fiscal Structure: An Empirical Assessment." Public Budgeting \& Finance 16 (1): 75-101. 
Musso, Juliet Ann. 2001. "The Political Economy of City Formation in California: Limits of Tiebout Sorting.” Social Science Quarterly 82 (1): 139-53.

Nall, Clayton. 2012. "The Road to Division: Interstate Highways and Geographic Polarization.” Unpublished manuscript, Stanford University.

Paul, Diane B. 1975. The Politics of the Property Tax. Lexington, MA: D. C. Heath and Company.

Poterba, James M. 1994. "State Responses to Fiscal Crises: The Effects of Budgetary Institutions and Politics.” Journal of Political Economy 102 (4): 799-821.

Putnam, Robert. 2007. "E Pluribus Unum: Diversity and Community in the $21^{\text {st }}$ Century." Scandinavian Political Studies 30 (2): 137-74.

Rosewater, Victor. 1968. Special Assessments: A Study in Municipal Finance. New York: AMS Press.

Rugh, Jacob S. and Jessica Trounstine. 2011. "The Provision of Local Public Goods in Diverse Communities: Analyzing Municipal Bond Elections.” Journal of Politics 73 (4):10381050.

Rusk, David. 2003. Cities Without Suburbs: A Census 2000 Update. Washington, DC: Woodrow Wilson Center Press.

Sears, David O. and Jack Citrin. 1982. Tax Revolt: Something for Nothing in California. Cambridge, MA: Harvard University Press.

Senate Committee on Local Government. 1986. "Interim Hearing on the Use of Benefit Assessments Since Proposition 13.” Los Angeles Convention Center. 22 October 1986. Skidmore, Mark. 1999. "Tax and Expenditure Limitations and the Fiscal Relationships Between State and Local Governments.” Public Choice 99: 77-102. 
Waters, Edward C., David W. Holland, and Bruce A. Weber. 1997. "Economic impacts of a property tax limitation: A computable general equilibrium analysis of Oregon's measure 5." Land Economics 73(1): 72-89. 
Table A1: Poisson Regression fo Club Special Assessments with Multiplicative Interaction Effect

$\begin{array}{ll}\text { City Median Income } & \begin{array}{l}0.024^{* *} \\ (0.010)\end{array} \\ \text { Zestimate } & 0.004^{* * *} \\ & (0.002) \\ \text { City Median Income X Zestimate } & -0.000^{* * *} \\ & (0.000) \\ \text { City Ethnic Diversity } & 2.715^{* * *} \\ & (0.854) \\ \text { Built 1931-1950 } & -0.706 \\ & (0.560) \\ \text { Built 1951-1978 } & -0.54 \\ & (0.510) \\ \text { Built 1979-2000 } & 0.957^{*} \\ & (0.541) \\ \text { Built 2000-2010 } & 2.425^{* * *} \\ & (0.552) \\ \text { City Population } & 0.003^{* *} \\ & (0.001) \\ \text { City Population Density } & -0.131^{* *} \\ \text { Constant } & (0.062) \\ & 0.732 \\ \text { Observations } & (1.171) \\ \text { Wald Chi Squared (df) } & \\ \text { Pseudo LogLiklihood } & 609 \\ \text { Pseudo R-Squared } & 282.5 \\ & -70872 \\ & 0.51 \\ & \end{array}$

Notes

Robust standard errors clustered by Census place in parentheses.

Pseudo R-Squared computed without clustering.

$* * * \mathrm{p}<0.01, * * \mathrm{p}<0.05, * \mathrm{p}<0.1$ 